\title{
Mourning Doves in Florida ${ }^{1}$
}

\section{William M. Giuliano, James F. Selph, Kurt Hodges, and Nick Wiley ${ }^{2}$}

While many species of dove live in Florida, the mourning dove (Zenaida macroura) is the only dove species native to the state (Figure 1).

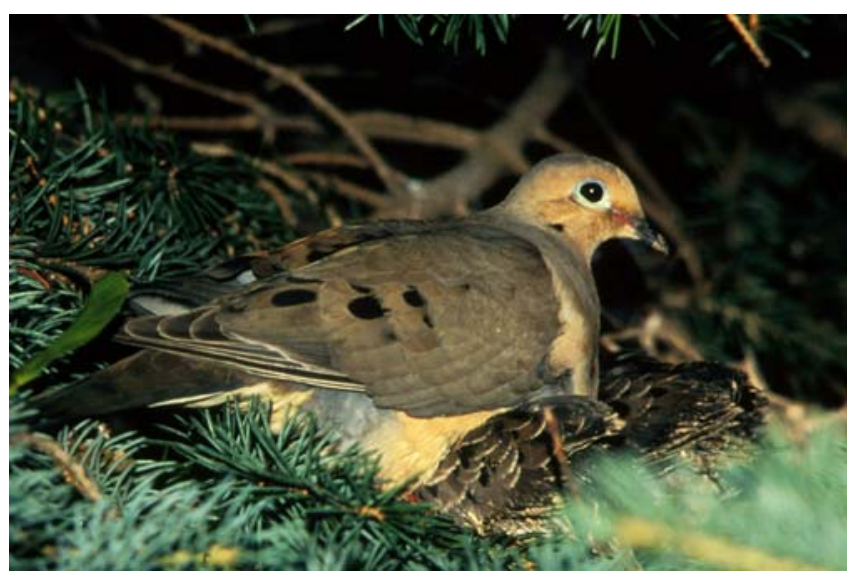

Figure 1. Mourning doves are the most widely distributed and only native species of dove in Florida. Credits: J.C. Leupold, U.S. Fish and Wildlife Service.

Many dove species that reside in Florida, while not native, are state and federally protected, including the common ground dove (Zenaida passerina), Inca dove (Columbina inca), Key West quail-dove (Geotrygon chrysie), ruddy quail-dove (Geotrygon Montana), scaly-naped pigeon (Columba squamosa), white-winged dove (Zenaida asiatica), white-crowned pigeon (Columbina leucocephala) and Zenaida dove (Zenaida aurita). There are also other species of dove residing in Florida that are not protected and considered exotics in the United States; examples include the diamond dove (Geopelia cuneate), ringed turtle dove (Streptopelia risoria), rock dove or common pigeon (Columba livia), and Eurasian collared or ring-necked dove (Streptopelia decaocto). Being the most widely distributed and only native species of dove in Florida, mourning doves will be the focus of this report.

\section{Distribution and Status}

Mourning doves can be found throughout southern Canada, all of the U.S. and Central America, and most of the Caribbean Islands. Found throughout Florida, the greatest numbers of mourning doves appear to be in the central portion of the state. Florida populations increase during the winter months, when the resident population is supplemented by birds migrating in from the north. During the past 40 years, dove populations have remained relatively stable in the eastern U.S., with a $1 \%$ increase during the last 10 years. In Florida, dove

1. This document is WEC 226, one of a series of the Department of Wildlife Ecology and Conservation, Florida Cooperative Extension Service, Institute of Food and Agricultural Sciences (IFAS), University of Florida. First published: August 2007. Please visit the EDIS Web site at http://edis.ifas.ufl.edu for more publications.

2. William M. Giuliano is a Professor and Wildlife Extension Specialist and James F. Selph is the Desoto County Extension Director; Florida Cooperative Extension Service, Institute of Food and Agricultural Sciences, University of Florida, Gainesville, FL 32611. Kurt Hodges is the Small Game Management Program Assistant Coordinator and Nick Wiley is the Director, Division of Hunting and Game Management, Florida Fish and Wildlife Conservation Commission, Farris Bryant Building, 620 S. Meridian Street, Tallahassee, FL 32399.

The Institute of Food and Agricultural Sciences (IFAS) is an Equal Opportunity Institution authorized to provide research, educational information and other services only to individuals and institutions that function with non-discrimination with respect to race, creed, color, religion, age, disability, sex, sexual orientation, marital status, national origin, political opinions or affiliations. U.S. Department of Agriculture, Cooperative Extension Service, University of Florida, IFAS, Florida A. \& M. University Cooperative Extension Program, and Boards of County Commissioners Cooperating. Larry Arrington, Dean 
populations increased by $2 \%$ during the past 40 years, but decreased slightly ( $2 \%$ ) during the last 10 years. Throughout the U.S., the number of dove hunters and birds harvested annually has been declining. Hunting, which typically takes $10-15 \%$ of the fall population, does not appear to be a significant problem for doves or an important factor in population declines. The primary reason for declines in many dove populations is the loss and degradation of breeding and foraging habitat.

\section{Biology}

Mourning doves can reach 4 ounces in weight; 10-11 inches in length (head-to-tail); are grayish-brown above and buff-colored below with black spots on the wings; and have a black bill, a thin neck, and a pointed tail. The average life span is 1 year, with a longevity record of 19.3 years in the wild. Mourning doves can suffer from a variety of diseases and parasites (e.g., avian pox, various bacterial infections, coccidiosis, helminthes, and mites), but none appear to cause significant mortality or affect populations. Extreme weather conditions, predation, and accidents are the greatest mortality factors--4-5 times greater than harvest-related mortality. The most important dove predators include fast, maneuverable birds of prey, like Coopers and sharp-shinned hawks, peregrine falcons, and merlins. Raccoons, feral cats, dogs, and rat snakes also regularly prey on doves.

In Florida, mourning doves may produce as many as 5-6 clutches (nests) of 2 eggs each year. While most nesting occurs February-October, nests can be found at any time of the year. Eggs are incubated for about 2 weeks and it typically takes chicks 14-15 days to leave the nest after they hatch. While in the nest, nestlings are fed "milk" produced in the crop of both adults. Adults continue to care for young for another 10-12 days after they leave the nest.

Throughout much of their range, mourning doves are migratory, moving south or southeast in fall (September-November) and north or northwest in spring (April-May). Florida's population contains many resident birds that remain in an area year-round or only make short-distance movements. Resident birds, as well as those that have completed a migration, range over areas of up to 5 miles each day, but usually less.

\section{Habitat}

Historically, mourning doves inhabited open forests and edges between forest and prairie, avoiding deep woods and extensive forest tracts. However, doves are very adaptable and now are found in a variety of habitats, including agricultural, suburban, and urban areas.

Doves prefer to nest in trees and shrubs along woodland and grassland edges, with the highest breeding densities often found in agricultural areas. Nests are typically found on horizontal tree and shrub limbs, and are made of twigs, grass, pine needles, and moss. They will also nest on building ledges, rain gutters, hanging flowerpots, and, occasionally, on the ground (Figure 2).

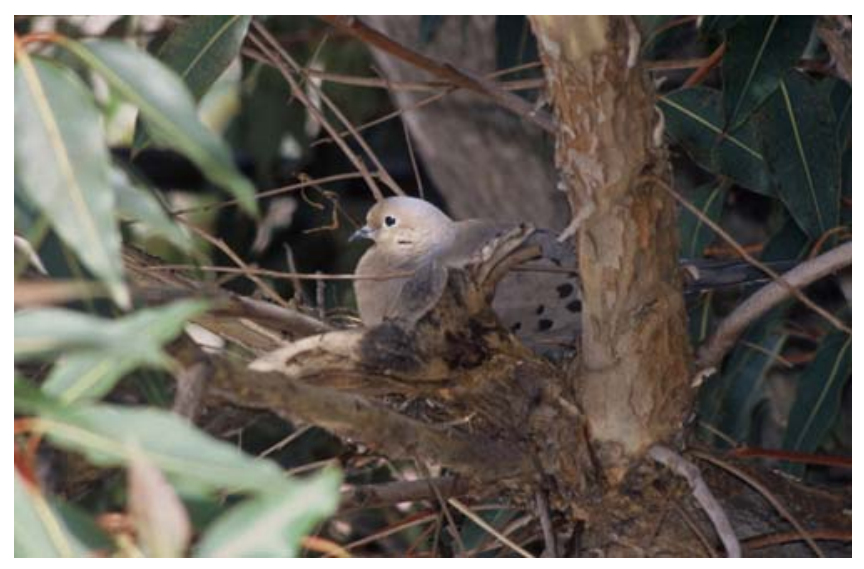

Figure 2. Doves prefer to nest in trees or shrubs on horizontal limbs. Credits: L. Karney, U.S. Fish and Wildlife Service.

While many past land uses and human-induced changes to the landscape have benefited doves by providing quality foods and nesting cover, recent changes may be a significant source of habitat loss and degradation. These include more intensive and cleaner farming practices (e.g., loss of brushy fencerows) and changes in land-use (e.g., from agriculture to intensive forestry, grains to cotton, shrublands to pasturelands and forest, and urbanization). These practices often reduce the quality and quantity of breeding and foraging habitat. 
The mourning dove diet consists of primarily plant material $(99 \%$ or more; almost all of which is seeds), with just a trace of animal matter, including small insects. Doves require a small amount of grit (small pieces of sand or gravel) and water to aid in digestion. Grass seeds, from both native and cultivated plants, are preferred dove foods. However, seeds from other types of plants are also used. Dove foods include Poa grasses, barnyard grass, Johnson grass, bristlegrass, crabgrass, paspalums, foxtails, browntop millet, Proso millet, Japanese millet, other millets, barley, sorghum, oats, wheat, corn, sesame, buckwheat, peanuts, cowpeas, soybeans, sunflowers, crotons, mustards, ragweeds, pokeweed, pine, and sweetgum. Doves get their food from the surface of the ground. However, with weak feet and poor scratching ability, foods need to be on open ground and plainly visible (Figure 3 ).

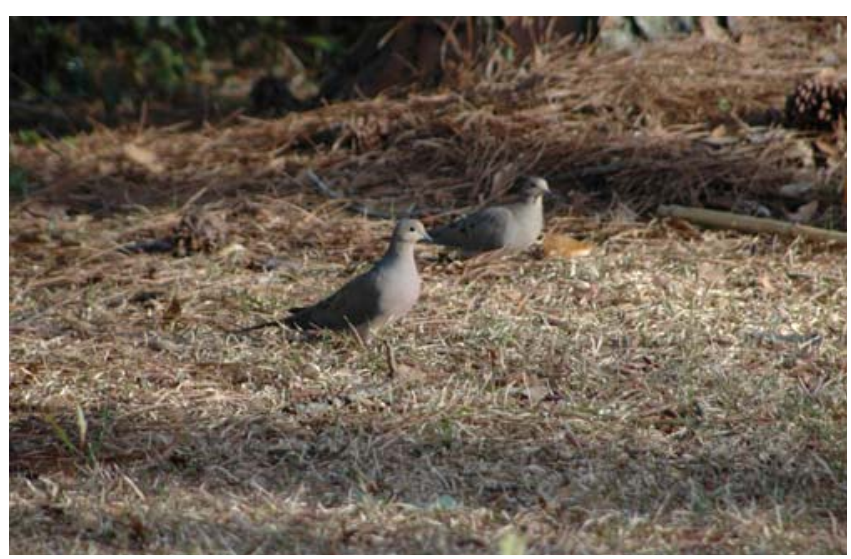

Figure 3. Doves get their food from the surface of the ground. However, with weak feet and poor scratching ability, foods need to be on open ground and plainly visible. Credits: W. VanDyk Evans, www.bugwood.org.

Ideally for doves, an area will include $60-70 \%$ openings (e.g., dove fields, agricultural crops [particularly grains and other grasses], pasture, and fallow fields); $28-38 \%$ forests, woodlands, and shrublands (particularly areas with a lot of edge, mature fencerows, and similar habitats); and $2 \%$ open water. These three habitat components should be highly interspersed to minimize travel between them.

\section{Management}

Management for doves should focus on providing the mix of habitats described above. Most often, this involves developing nesting habitat near quality food sources (Figure 4). Nesting habitat can be created by allowing tree and shrub growth along fencerows and adjacent to fields, and "softening" the woodland edges by allowing shrubs and small trees to form thickets. Such areas should be near quality food sources, either planted or naturally ocurring. Planting quality foods (i.e., establishing a dove field) can be very beneficial for doves, as it allows their proper positioning relative to breeding habitat, and for sportsmen, as it will attract birds for hunting. Soil conditions and preparation, as well as the method and timing of planting, will vary with the plant species used.

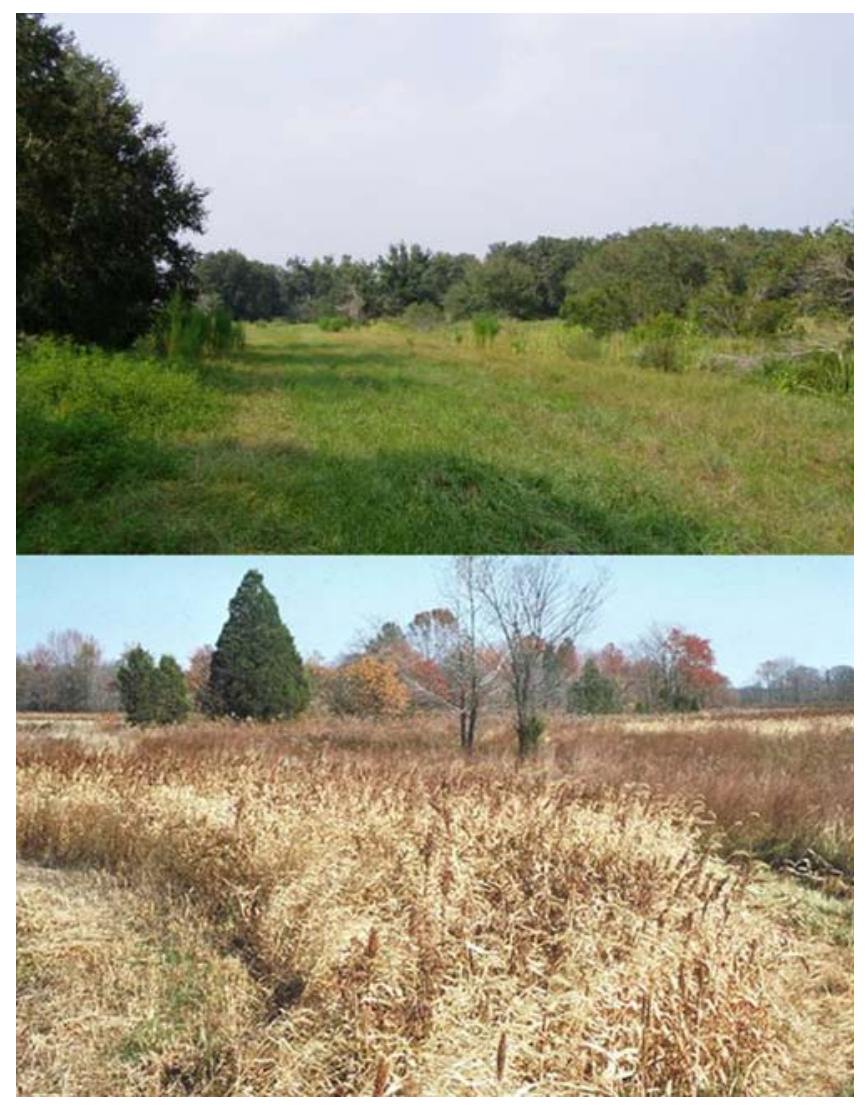

Figure 4. Management for doves should focus on providing shrubs and trees for nesting along habitat edges (top), near foraging areas of grasses and grains (bottom). Credits: W.M. Giuliano (top) and U.S. Department of Agriculture (bottom).

Well-prepared dove fields also will serve as an attractant to migrant doves, and may encourage them to stop and stay at a particular location if the food supply remains high. The increased ease of foraging and food quality also should increase body weight and overall conditioning and enhance the reproductive potential of individual doves. For more information 
on dove fields, see UF/IFAS Extesnion Fact Sheet

WEC 225 Dove Fields in Florida

(http://edis.ifas.ufl.edu/UW265).

\section{Hunting}

In Florida, both mourning doves and white-winged doves are migratory, upland game birds pursued by countless sportsmen. Because they are migratory species, both the U.S. Fish and Wildlife Service and Florida Fish and Wildlife Conservation Commission (FWC) have management and regulatory authority over them. However, only a valid Florida hunting license and free Florida migratory bird permit are required to legally hunt them. The diamond dove, ringed turtle dove, rock dove or common pigeon, and Eurasian collared or ring-necked dove are considered exotic species, not game animals, and are not afforded any state or federal protection. Therefore, they may be hunted year-round with no bag limit, as long as the hunter has permission of the landowner and is not breaking any laws concerning the discharge of firearms. No hunting license is required. However, if, in the process of hunting any of these non-protected species of dove, a hunter inadvertently shoots a mourning or white-winged dove outside of the dove season and without a license, the hunter is in violation of the law! It is often difficult to tell the various dove species apart, particularly on the wing. Therefore, it is recommended that hunters pursuing any species of dove have valid hunting permits and only pursue them during the dove hunting season.

If planted areas (dove fields) are to be used for hunting, certain guidelines must be followed. It is illegal to hunt doves over bait. Historically, there has been much confusion over what constitutes baiting and hunting over bait. More detailed information on dove fields, baiting, and the FWC can be found at:

- UF/IFAS Extension Fact Sheet WEC 225 Dove Fields in Florida (http://edis.ifas.ufl.edu/UW265)

- U.S. Fish and Wildlife Service, Office of Law Enforcement: Dove Fields and Baiting: http://www.fws.gov/le/huntfish/dovebaiting.htm

- FWC Regional Offices: http://myfwc.com/Contact/regnoffc.htm
- Dove Hunters' Hotline:

http://myfwc.com/special/dove/ 